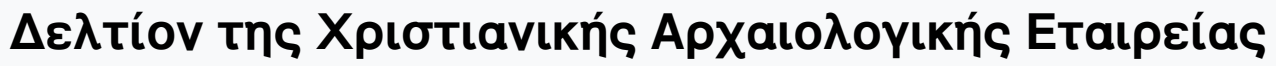

Tó 10 (1981)

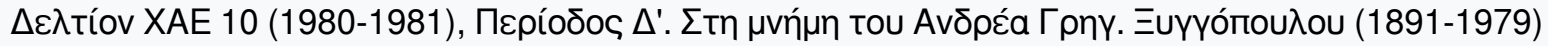

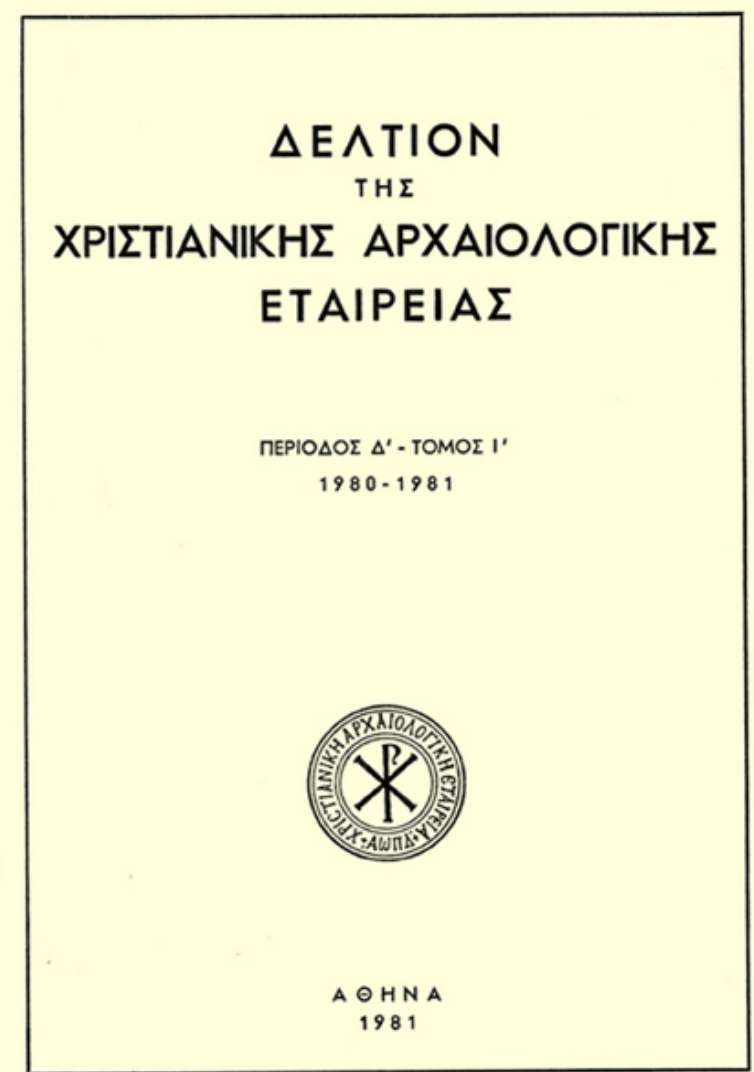

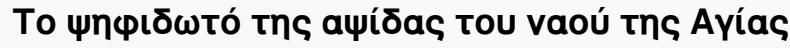

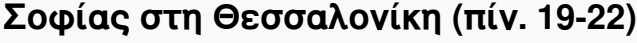

Robin CORMACK

doi: $10.12681 /$ dchae.902

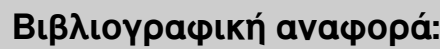

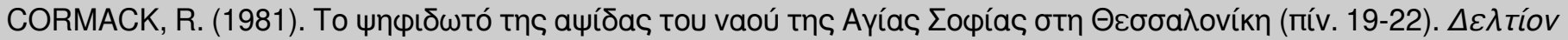

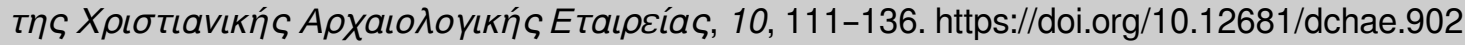




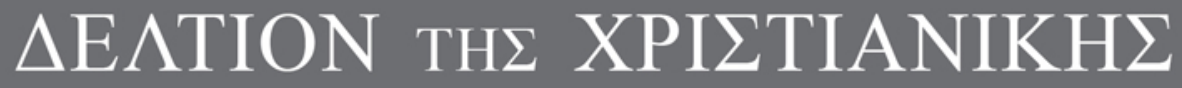 APXAIO $\Lambda$ OГIKH $\Sigma$ ETAIPEIA $\Sigma$}

The Apse Mosaics of S. Sophia at Thessaloniki (pl. 1922)

Robin CORMACK

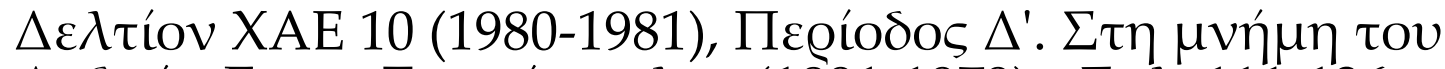

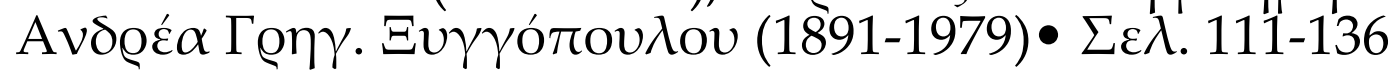

A@HNA 1981 


\section{THE APSE MOSAICS OF S. SOPHIA AT THESSALONIKI}

(PL. 19 - 22)

The study of Byzantine mosaics has undergone a virtual revolution in recent years and this is due in the main to a new sensitivity towards the role of the individual artist in the execution of each decoration. Analysis of mosaic in its setting and a knowledge of the precise technical means through which the artist achieved his effects in each part of a building is now to be considered an essential part of the art historical study of the medium ${ }^{1}$. Such study can, however, only be successfully achieved with the help of close observation of the tesserae and their setting plaster which must be carried out from scaffolding. Since the erection of satisfactory observation platforms is expensive and infrequent, it is important not to miss the opportunity when scaffolding is set up to make a full technical record of the mosaic, and there is a strong case for special international cooperation of scholars to ensure that the mosaics are studied by experienced observers and, conversely, to ensure the existence of such experience. Unfortunately the modern study of the church of S. Sophia at Thessaloniki is a history of lost opportunities, and despite the fact that scaffoldings have already been set up in the church three times this century, the technical evidence of the mosaics has not been systematically studied ${ }^{2}$. As a result of the serious damage to the structure of the monument and fractures in the mosaics of the cupola caused by the earthquake and tremors in the summer of 1978, scaffolding has again been of necessity erected in the nave of the church. This time the opportunity for a thorough study of the important mosaics of the church must not be lost, and the aim of this paper is to state some of the questions which require examination in the sanctuary mosaics in the hope that

1. Cf. I. Andreescu, The Corpus for Wall Mosaics in the N. Adriatic Area, Bulletin de l'Association pour l'étude de la mosaïque antique 7 (1978), 317 - 323.

2. To my knowledge, scaffoldings were put up in S. Sophia in 1907 (for restoration as a mosque; the present interior painting belongs to this period), in 1941 (work began in September after bomb damage in February), and in 1961 (as part of a general project of restoration). 
remarks which derive from study without the assistance of scaffolding will be soon superseded ${ }^{3}$.

At the present time the only substantial technical observations which have been reported about the mosaic representation of the Virgin and Child in the apse were made by Andreas Xyngopoulos. He was able to see the mosaics on a scaffolding put up after repairs were necessitated in the church because of bomb damage in 1941; what he saw was subsequently reported by Kalligas and Galavaris ${ }^{4}$. Xyngopoulos, when I discussed these reports with him, maintained that he had been correctly reported and that his observation was correct. Again it is an issue which needs a new scaffolding for its resolution.

Despite the lack of information about the architecture of the church and its various structural phases as well as the absence of an objective description of the mosaics, scholars have not been reticent to express (divergent) opinions about the dating and hence the historical significance of S. Sophia and its mosaics ${ }^{5}$. There are only a few points on which there seems to be any unanimity, and it seems worth setting these down, not because they are necessarily correct but as a basis for discussion:

3. This paper depends in part on sections of my thesis Ninth Century Monumental Painting and Mosaic in Thessaloniki, London, 1968. My work has been assisted by the loan of a camera belonging to the Central Research Fund of London University.

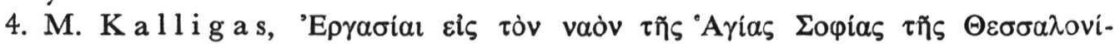

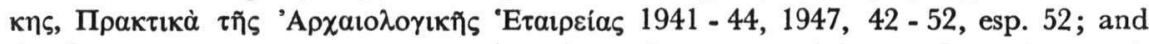
G. G a l a va ri s, The representation of the Virgin and child on a 'Thokos' on seals of Constantinopolitan Patriarchs, $\triangle$ XAE 2 (1960 - 61), 153 - 81.

5. The literature on this church has been marked by a more than usual repetition of unsubstantiated opinions. Early in this century many observations were made in Thessaloniki by the French architect M. le Tourneau during studies in 1905, 1907 and 1909. He sent his notes to Ch. Diehl, who published them and added his own interpretations e.g. M. le Tournea u et Gh. Diehl, Les Mosaïques de Sainte-Sophie de Salonique, Fondation E. Piot Monuments et Mémoires 16 (1909), 39 - 60. Diehl did not rethink his interpretation on his visit to the city in 1909, and was later (after the death of le Tourneau in 1912 at the age of 37) to incorporate the photographs and (undigested) notes in the joint publication: Ch. Die hl, M. l e Tourneau, et $\mathrm{H}$. S a 1 a d i n, Les Monuments Chrétiens de Salonique, Paris, 1918. The interpretations of Diehl have gained a surprising currency. For example, his division of the cupola Ascension composition into two periods, though rejected by all recent observers, is maintained as current opinion by $R$. J a n i n, Les Églises et les Monastères des grands centres byzantins, Paris, 1975, p. 410. The thesis on the church by M. Kallig a s, Die Hagia Sophia von Thessaloniki, Würzburg, 1935, was very concise, but its conclusions have often been accepted without any consultation of the publication. 
1. The vaulting of the sanctuary and any part of the superstructure which is accepted as part of this phase cannot be later than $780-797$ (the date given by the imperial monograms which appear in the mosaic decoration of this sanctuary vault) ${ }^{6}$.

2. The sanctuary mosaics consist of (at least) two phases, for the throne on which the Virgin sits and the footstool on which she rests her feet cut into and interrupt the liturgical inscription which runs horizontally around the base of the conch. Consequently this representation of the enthroned Virgin and Child is relatively later than the liturgical inscription and any mosaics which are homogeneous with it?

3. The cupola mosaics consist of (at least) two phases, for the floral garland which runs around the base of the scene of the Ascension cuts into the two sections of a donor inscription which (assuming it was originally executed in a complete form) must therefore be relatively earlier than the garland beside it ${ }^{8}$.

4. The fresco decoration of saints in the narthex represents a phase of work in the church which may be dated on the basis of style to the first half of the eleventh century?

In the form in which I have set out these propositions I believe they would command a measure of assent, but all are in need of refinement by

6. The most recent publication of the monograms is by J. M. S p i e s e r, Les inscriptions de Thessalonique, Travaux et Mémoires 5 (1973), $145-80$, esp. 80 (this study needs supplementation, cf. review of $\mathrm{H}$. H u n g e r in JÖB 23 (1974), 316, and D. F e is sel and J. M. S pi ese r, Les inscriptions de Thessalonique, supplément, Travaux et Mémoires 7 (1979), 303 - 348.

7. The main studies are by $\mathrm{S} t$. P e le k a $\mathrm{n}$ id e s, I Mosaici di S. Sophia di Salonicco, Corso di Cultura sull'arte Ravennate e Bizantina XI (1964), 337 - 349, and Bemerkungen zu den Altarmosaiken der Hagia Sophia zu Thessaloniki und die Frage

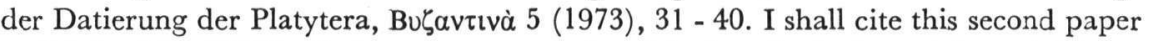

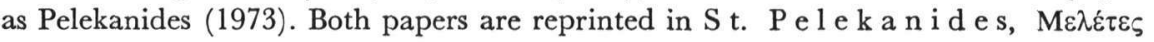

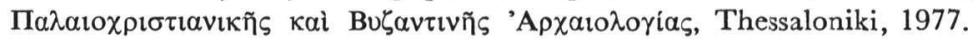

8. The problem of the disturbance of the cupola inscriptions was noticed by C. B a y e t, Mémoire sur une mission au Mont Athos, Paris, 1876, p. 325 - 32; and was duly emphasised by le Tourneau. The most recent consideration of the problem is

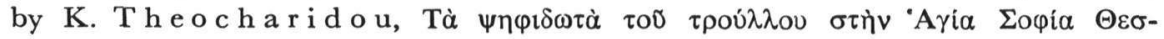

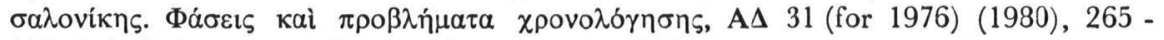
273. I shall cite this as Theocharidou (1980).

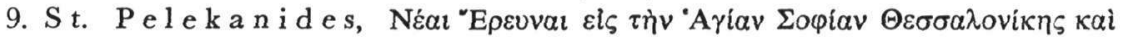

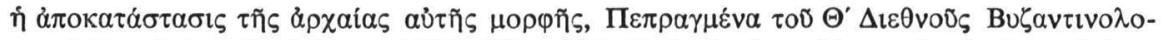

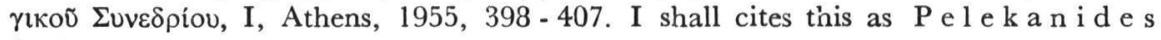
(1955). 
fresh technical observations. While one of the lessons for the Byzantinist of the recent excavations at the Constantinopolitan church now converted into the Kalenderhane Camii is the frequency of structural and decorative alterations on a site in church use from the pre-iconoclastic period ${ }^{10}$, yet in a structure of the size of S. Sophia it is hard to believe that all the expensive alterations detected in various parts of the building were chronologically independent of each other. Although it is my intention here to concentrate on the question of the apse mosaics, it would be incautious to consider these as a unit whose history is independent from that of the rest of the monument, and some mention will be made of the other decorations in the church which affect the internal chronology of S. Sophia ${ }^{11}$.

\section{THE FIRST DECORATION OF THE SANGTUARY}

The obvious place to begin an investigation of the chronology of the church and its decoration is at the mosaic monograms and inscription in the barrel vault of the sanctuary, for these supply the only objective fixed point. The three cruciform monograms on the south side of the vault are today legible, but on the north side the combination of damage and the overpaint of the 1907 restoration (when the building was planned to continue in use as a mosque) obscures all but the easternmost monogram. Fortunately the evidence was observed before this restoration and a transcription has been several times published ${ }^{12}$. On the north side the monograms contained an invocation for an emperor Constantine, while the equivalent three on the south side were on behalf of an empress Eirene. The third invocation was for a bishop Theo-

10. For the excavation of C. L. S trike r and D. K u b a n and its implications cf. T. F. M a th e w s, The Byzantine Churches of Istanbul, Pennsylvania State U. P., 1976 , p. $171 \mathrm{ff}$.

11. K. Theocharidou has recently investigated the masonry phases of the church made more visible after the removal of plaster. G. Lavas informs me that a full architectral survey has been made since the earthquake of June 1978, and a number of new finds made. For a summary of archaeological work on the site, see P h. A. D r o s o -

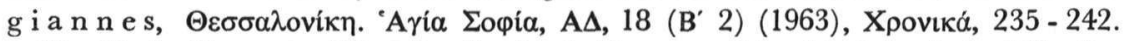

12. Cf. J. K u r t h, Die Mosaikeninschriften von Saloniki, Athenische Mitteilungen, 22 (1897), 463 - 472 (critical remarks on this transcription by E. W e i g a n d, Zur Monogramminschrift der Theotokos - (Koimesis) Kirche von Nicaea, Byzantion

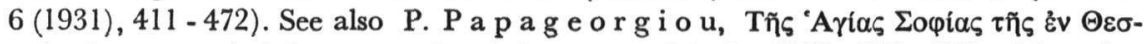

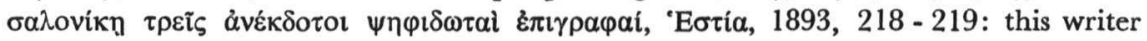
also treated inscriptions in the church in 'Eøtía (1892), 394 - 395 and (1893), 317. J. M. S pi eser has a satisfactory entry. 
philos and is written out in full between the monograms on each side of the vault ${ }^{13}$. The period to which these commemorations belongs can be deduced without ambiguity: the 'joint' reign of Eirene and Constantine VI may be dated between 9 September 780 and the Spring of 790 and between December 790 and 15 August 797, and Theophilos is documented by his signature in the acts of the Council of Nicaea of $787^{14}$.

Although these mosaics of the sanctuary are clearly dated to the late eighth century, so far there has been no careful technical examination to clarify the extent of the mosaics of this period or their precise relationship to the structure of the $\operatorname{church}^{15}$. It therefore seems justifiable to propose an interpretation in the hope that it will soon be tested during work on the church ${ }^{16}$.

13. Pelekanides (1973) believed that this combination of monograms and inscription denoted the initiative for the work to the archbishop between 787 and 797; this idea lacks proof.

14. M a n si, XIII, 133E. J. S m i r n ov, On the date of the mosaics of S. Sophia in Thessaloniki, (in Russian), VV 1898, 365 -392, esp. 380, interprets Theophanes as referring to Theophilos as archbishop by 785 . This conclusion is criticised by $\mathrm{L}$. P e t i t, Les Évêques de Thessalonique, Échos d’Orient 4 (1900-1), esp. 215 - 216.

15. The present sources of information are the works of le Tourneau, Kalligas and Pelekanides mentioned above. Kalligas supposed that the monograms together with the panels above were an insertion into a previous scheme consisting of a cross against a gold ground in the apse, and a second cross in an aureole against a gold ground above the sanctuary. The second of Pelekanides' opinions was that the barrel vault decoration over the sanctuary was of the same date as the monograms, but that at a previous time the apse was decorated with a cross and the liturgical inscriptions. The cross at the apex of the sanctuary was made to replace that in the apse when that was removed to make way for the new figural composition. Neither of these observers justified their conclusions with a description of the technical evidence.

16. What follows is the hypothesis put forward in my thesis (1968). The same conclusion was reached by H. B u chwald, The Church of the Archangels in Sige near Mudania, Graz, 1969, esp. p. 43ff. He also took the non-figurative mosaics of the sanctuary to be of one period, that of the foundation of the church. This conclusion was specifically rejected by R. Kr a u th e i m e r, Early Christian and Byzantine Architecture, second edition, Pelican, 1975, p. 514, on stylistic grounds; K r a u t h e im e r had in his first edition (1965), p. 290, followed Kalligas in dating the church "as early as the first quarter of the eighth century". A. Gr a b a r, L'Iconoclasme byzantin, Paris 1957, esp. p. 153ff. and 172ff. assumed the non-figurative decoration of the sanctuary and the foundation of the church to belong to $780-797$, and perhaps before 787. Pelekanides (1973) rejected this proposal. C. M a n go, The Byzantine Church at Vize (Bizye) in Thrace and St. Mary the Younger, Zbornik Radova Vizantoloskog Instituta 11 (1968), 9 -13, inclines to the late-eighth - century date for S. Sophia; and a dating to c. $784-787$ is regarded as plausible by P. S p e c k, Kaiser Konstantin VI, Die Legitimation einer fremden und der Versuch einer eigenen Herrshaft, München, 1978, II, p. 533 - 534, note 220. 
To the observer at floor level there is no apparent suture between the monograms and the mosaics of the barrel vault or between the mosaics of the barrel vault and those of the apse. It can therefore be proposed that the programme of work undertaken at the time of setting the monograms was as follows. In the extensive barrel vault of the sanctua$\mathrm{ry}^{17}$, above the monograms, were set two symmetrical panels consisting of a rectilinear framework of six horizontal courses (each staggered like a brick wall). Each frame encloses a small 'greek' cross of silver tesserae outlined in red or, alternately, a green vine leaf. The arms of these crosses are slightly flared and terminate in a pair of tear-drop serifs. The apex of this vault was decorated with a large cross inside a circular aureole against a gold ground. Superficially it appears 'greek' in form, but the arms on the east-west axis are actually longer than those on the northsouth axis, and the east arm is slightly longer than that on the west side. The arms are filled with gold tesserae within an outline of three rows of red tesserae. The arms are slightly flared and terminate in a pair of tear-drop serifs, the cores of which consist of whitish marble tesserae, outlined by two rows of red tesserae. Rays of light radiate from between each arm and from the end of each arm. The ground of the aureole is made up of four concentric rings of four hues of blue. In the outermost ring are pairs of six-pointed stars of gold set against a lighter blue circle. The aureole is completed with a variegated ring of nine hues (inner to outer: dark blue or black; green; light olive; white; fawn; orange; vermilion; dark blue or black).

Below the monograms on the south side the painted early-twentiethcentury border appears to be false to the design of the few tesserae which show through it ${ }^{18}$. The mosaic border (which fills in the space between the monograms and the moulded cornice) seems to have contained a plant scroll, reflected in two axes to form a symmetrical figure. This ornamental border would therefore seem to differ in its design from its continuation at right angles around the east side of the barrel vault. This vertical continuation is concave in shape and consists of alternating

17. Deep sanctuaries are found in Thessaloniki also at the Rotunda and Acheiropoietos: the suggestion is made by W. E. K l e i n b a u e r, Report on the Earthquakes in Thessaloniki, Archaeology, Sept. - Oct. (1978), 60, that the apses of both these churches were rebuilt in the sixth century.

18. B u ch wa ld, cited in note $16, \mathrm{p} .43$, note 196 , claims that the painted restoration is faithful to the mosaic design. This was not my impression but the point is far from certain, and needs investigation; one would expect this border to conform either with its continuation vertically or with the apse border. 
plant and geometrical motives. Three points about it are to be noted: the similarities of the plant forms in the horizontal and vertical borders, the similarity of the framing element between both borders and the carpet decoration of the vault, and the absence of a visible suture at any place. Furthermore, there is no sign of a suture in the mosaic surface which completes the transition from the barrel vault to the conch of the apse. In this undulating area of transition there are three separate bands with four dividing frames, of which the two outer and two inner are mirror images of each other. The central flat band is composed of a monumental inscription, while the third convex band consists of alternating double forms with a trefoil between two entwined heart shapes. This band surrounds the conch of the apse, and in its turn appears entirely homogeneous with the gold ground and with the horizontal inscription which is set into the lowest of the three green registers ${ }^{19}$.

The present representation of the Virgin and Child in the apse can be demonstrated today to be a later insertion into the decoration in this area on the grounds that the horizontal inscription is now incomplete and that its central part was removed to supply space for the insertion of the footstool of the throne. It was much easier to see evidence of this Byzantine alteration to the apse scheme before the restoration work in S. Sophia of 1941 when sections of the original tesserae around the Virgin were removed and replaced ${ }^{20}$. Fortunately some of the information lost at that time can be recovered by study of older photographs (see Plates $19 \mathrm{a}$ and 22) ${ }^{21}$ These photographs show that the Virgin was surrounded by a suture which was most obvious on the right side of the halo. What can safely be deduced is that at some time the original central motive of the apse was cut out, and into this space was set the enthroned Virgin with a new trim around the figure and a new setting of the gold ground between the figure and the original ground of the apse. Since at some places the join between the two phases was not quite flush, it was visible

19. There are no significant discrepancies between the letter forms of the three inscriptions.

20. The lateral arms of the cross were replaced with reset tesserae, and the line of the suture was masked.

21. Plate 19a was photographed by le Tourneau in 1907 from the scaffolding: it was published in the article of 1909 , p. 50, fig 8, and in the book of 1918, p. 140, fig. 59; Diehl incorrectly described it as taken from the ground.

Plate 22 is after D. B a u d - B o v y, Salonique, la Ville, des Belles Églises, Geneva, 1919, with photographs taken by F. Boissonnas after 1912; cf. also P. A. U n d e r w o o d, The Evidence of Restorations in the Sanctuary Mosaics of the Church of the Dormition at Nicaea, DOP 13 (1959), 235 - 342. 
to the naked eye and in the course of time it collected dirt. This suture around the Virgin is the only sign of any deviation from the original scheme to which all the rest of the sanctuary mosaics can therefore with some reason be ascribed. It is this conclusion which is proposed here.

Study of the photographs shows that the method of operation in inserting the Virgin did not entirely mask the original central motive of the apse. On each side of the Virgin at shoulder level, instead of hacking out the complete original mosaic, all that was done was to pick out the rows of coloured tesserae and to replace them with gold tesserae. Since the new tesserae were not identical in appearance, or in their plane, with the original gold tesserae, a 'ghost' of the original composition remained visible. The original motive can be reconstructed without difficulty. It was a vast gold cross, outlined by dark tesserae, similar in form to that in the apse of S. Eirene in Constantinople ${ }^{22}$. Its horizontal arms were plain, without any infilling decoration such as of jewels, and they were slightly flared and terminated in a pair of tear-drop serifs. The vertical arms were entirely removed at the time when the Virgin was set; they presumably resembled S. Eirene too. Probably, then, the plain cross was set on a stepped base, the bottom edge of which would have rested above the horizontal inscription.

The first decoration of the sanctuary of S. Sophia consisted, according to the interpretation offered here, of a non-figurative scheme which gave considerable emphasis to the symbolism of the cross. The problem remains whether this decoration, datable to the period 780 to 797 , was contemporary with the building of the church. The content of the two liturgical inscriptions is a relevant factor in reaching a decision. The inscriptions read as follows:

22. The apse mosaic of S. Eirene dates after 26 October 740. Pelekanides (1973) repeats the mistake of G r a b a r, L'Iconoclasme byzantin, Paris, 1957, p. 153, (due to an incorrect transcription of Theophanes) that the earthquake was in 732 . Pelekanides thought that the date 740 referred to the apse mosaic, and this misapprehension may have influenced his dating of the apse cross in Thessaloniki. Presumably the restoration and redecoration of S. Eirene took place in the reign of Constantine V, cf. R. G o r m a c k, The Arts during the Age of Iconoclasm, "Iconoclasm", edited by A. Bryer and J. Herrin, Birmingham, 1977 p. 35 - 44. Recently the curious view has been put forward by S. G e r o, Byzantine Iconoclasm during the reign of Constantine V, G.S.C.O. Subsidia 52, Louvain, 1977, p. 117, that "the only examples of iconoclastic art which can be securely attributed to the period of Constantine's reign are seals and coins". The surviving mosaics from the period and the literary records make this attempt to deny monumental church commissions during this reign quite untenable. 
inscription one (around the face of the apse semidome)

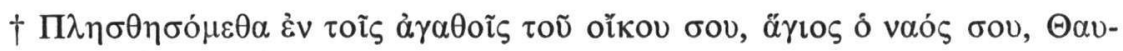

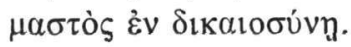

inscription two (around the base of the apse semidome)

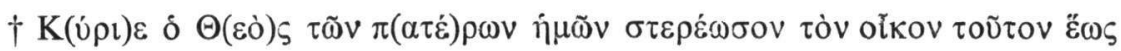

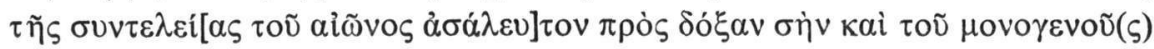

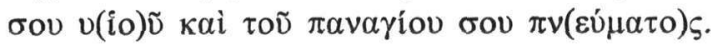

Inscription one is a quotation from Psalm 64 (v. 5), and the same passage appears in the similar position around the apse of $\mathrm{S}$. Eirene, but at greater length there since space was available to include the following verse. These words are spoken in the rite of the dedication of a church, and it was pointed out by Smirnov that inscription two is a conflation from various phrases also used in the encaenia ceremony. The mosaic insciptions therefore from a visual and permanent record of the prayers spoken when S. Sophia was consecrated, and their content is one further (though not conclusive) argument that the first mosaic decoration dates from the time of the foundation of the church ${ }^{23}$. It is to be hoped that the question can be decided on the basis of careful technical observations ${ }^{24}$.

The choice of a non-figurative scheme for S. Sophia in the late eighth century links it with the current decorations of the apses of S. Eirene and (presumably) S. Sophia at Constantinople, and it is unlikely that this connection with the Great Church of the capital is a coincidence, for there is a possible historical context for the building of the new large dom-

23. Cf. J. S m i r nov, cited in note 14. For the texts, see P. N. T re m pelas,

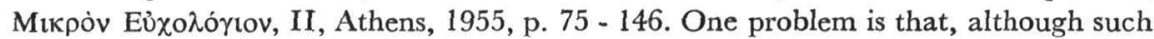
phrases occur in foundation decorations, in the apse of S. Eirene they occur at a time of a refoundation (for the use of the same phrases at the second inauguration of S. Sophia, in 562, see C. A. Try p a n is, Fourteen Early Byzantine Cantica, Vienna, 1968 , p. 141). Another complication on this site is that at present the chronological relationship between the disuse of the earlier basilica and the foundation of S. Sophia is unclear. However, even if it were to be argued that the sanctuary mosaics of S. Sophia belonged to a refoundation, it seems to me unlikely that the superstructure would be earlier than 780 .

24. M. le Tourneau, cited in note 5, reported that the tesserae were embedded in a plaster base which was laid directly onto stone which had been grooved diagonally to ensure adherence. This procedure has also been reported from San Marco in Venice, but it does not prove that the present mosaics belong to the original decoration of the apse. Presumably Le Tourneau made his observation at those areas of loss which were reset in 1941. 
ed church, the largest built in this city since the fifth century and the latest of its size. The historical circumstance which may explain the need for a new impressive church in the late eighth century in Thessaloniki was the official reorientation of the ecclesiastical jurisdiction of Illyricum from Rome to Constantinople ${ }^{25}$. Was the dedication, scale, and even the form of S. Sophia chosen for S. Sophia so that the new church could fulfil the role of a new cathedral for the archbishop? Its function as cathedral does appear to be documented from the end of the eighth century and thereafter.

The earliest mention of S. Sophia is in a letter of Theodore the Studite written in banishment in Thessaloniki in $797^{26}$. Theodore was sent to pray in S. Sophia before his reception by the (unnamed) archbishop (Thomas?), and the archbishop too prayed in his oratory, which sounds to have been in S. Sophia. The choice of this church for the rendez-vous implies that it was near the episcopal residence, if it does not prove that it was the cathedral. Athonite documents of the eleventh century are less ambiguous, and include more than one reference to the clergy of S. Sophia as belonging to the 'Great Ghurch' of Thessaloniki ${ }^{27}$. Pope Innocent III in a letter of 1212 refers to the church as the metropolis ${ }^{28}$, and after the Latin Occupation, S. Sophia remained the cathedral during the Palaeologan period. From the time of Symeon of Thessaloniki a number of useful liturgical texts survive which explain how the architecture of the church was used and which claim that cathedral liturgy in this church was the most authentic in the Byzantine world ${ }^{29}$. S. Sophia

25. For a considerable period of time the ecclesiastical jurisdiction of Illyricum lay officially in the hands of the Roman see, and the archbishop of Thessaloniki was the vicarius of Rome. This situation, however nominal in practice, came to an end either in the reign of Leo III or of Constantine V: for a bibliography on this problem, see G. Ostrogorsky, The Byzantine Background of the Moravian Mission, DOP 19 (1963), 3 - 18.

26. Epistles of Theodore the Studite, I, 3: M i g n e, PG 99, cols. 913 - 20, esp. 917C. Annunciation Day (25 March) fell on a Saturday in 797, and this is the year adopted by the editor of Migne, and also by P. S p e c k, cited in note 16, II, p. 713, note 54. Up to this time, the evidence is that the cathedral was the Acheiropoietos Basilica.

27. Cf. R. J a n in, cited in note 5, p. 407 , where these documents are s een to refer to S. Sophia as the cathedral.

28. R. J a n i n, op. cit. 407 - 451.

29. Cf. O. S trunk, The Byzantine Office at S. Sophia, DOP 9 - 10 (1955 6), 177 - 202. For the dating of liturgical manuscripts to the initiative of Symeon, see

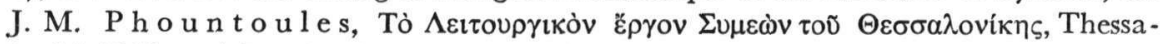

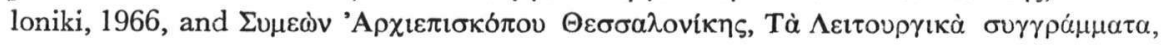


probably continued as the cathedral up to its conversion into a mosque which probably occurred in the first half of the sixteenth century (after which the Rotunda took over this function for a few decades until it too became a mosque in Hegira 999) ${ }^{30}$.

I Eủxaì кaì "Yuvol, Thessaloniki, 1968. Strunk reports that cod. Athens 2061 describes the psaltists in S. Sophia at Thessaloniki going up into the dome and from here singing their acclamations. Another manuscript, cod. Athens 2047 (dating between 1410 and 1423), gives the order of processions, mentions oratories, etc. On this see, J. D a rr o u z è s, Sainte-Sophie de Thessalonique d'après un rituel, REB 34 (1976), 45 - 78. Another important text with information about S. Sophia at this period is the cod. Athens 2953, see S. K u g e a s, Notizbuch eines Beamten der Metropolis in Thessalonike aus dem Anfang des XV. Jahrunderts, BZ 23 (1914-9) (1920), 143 - 63.

30 . The precise date of the conversion of $\mathrm{S}$. Sophia into a mosque remains an unresolved issue despite the apparent precision of many writers. The firmest recent statement on the problem is in the useful paper by M. Kiel, Notes on some Turkish monuments in Thessaloniki and their founders, Balkan Studies 11 (1970), 123 - 48, but this author does not take into account all the evidence. He states that the transformation of S. Sophia took place at the end of the sixteenth century in the climate of millenarianism as the Muslim year approached Hegira 1000, and he parallels it with the Rotunda (conversion dated by inscription to H. $999=1590$ ). Kiel supports his dating with reference to an Italian traveller who could in 1591 still see a representation of the Pantocrator in the dome of S. Sophia, a fact which Kiel interprets to prove that the conversion was very recent. This particular argument is unacceptable for several reasons: one is that the procedure of the concealment of Christian iconography was not undertaken immediately even in the church of S. Sophia at Constantinople. The overpainting of the figures in this dome (they were disguised as trees) may not have been much earlier than the fire of 1890 .

The following dates for the conversion of S. Sophia into a mosque are met in the literature:

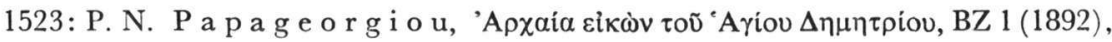
486 (transcription of Hegira 930).

1525: J. Ku r th, as cited in note 12, and G. I. The oc harides, 'O vaós

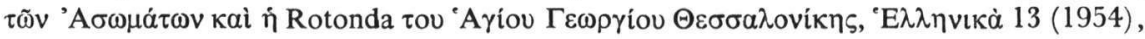
24 - 70. Theocharides trusts the date given by Kurth on the grounds that there seems to have been more precise information in the nineteenth century and now lost, and that Kurth through J. H. Mordtmanns might have had access to Turkish material.

1575: Di e hl, Le Tourneau, and Saladin, cited in note 5.

1589: Ch. Te xi e r and R. P. P ull a n, Byzantine Architecture, London, 1864. 143, give the date Hegira 993 without quoting their source; the proper transcription of the year is $1585 . \mathrm{M} . \mathrm{Kall} \mathrm{i} \mathrm{g} \mathrm{a} \mathrm{s,} \mathrm{cited} \mathrm{in} \mathrm{note} 5$, also gives this date.

The most important study on the problem in F. B a b i n g e r, Ein Freibrief Mehmeds II, des Erobers, für das Kloster Hagia Sophia zu Saloniki, eigentum der Sultanim Mara (1459), BZ 44 (1951), 10 - 20, who gives the reasons for dating th conversion between 1520 and 1536. The problems against accepting the opinion of Kiel lie in the following evidence:

a. The traveller who describes the Pantocrator in the dome was in fact the Venetian 
If the motivation for the construction of S. Sophia lay in the wish to provide a symbol of the closer connection of the see with the Patriarchate of Constantinople, the best circumstances for the project arose towards the end of the eighth century when purely defensive building would no longer be the priority in the region. The situation changed in 783 when Eirene sent her general Staurakios to Thessaloniki and Hellas with a large army ${ }^{31}$. The success of this campaign against the Sclaviniae was such that Staurakios in January 784 celebrated a triumph in the hippodrome at Constantinople, and in May of the same year Eirene and Constantine VI made a ceremonial visit (accompanied by the army and

ambassador of 1591, see B. Ce c chet ti, F. S t efani, and G. Berchet, Viaggio di un ambasciatore Veneziano da Venezia a Costantinopoli nel 1591, Venice,

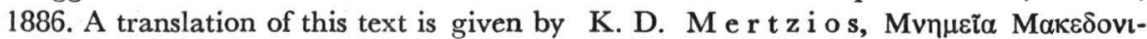

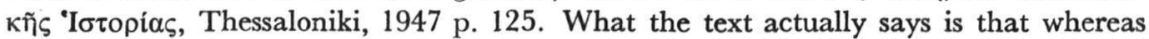
the Rotunda was turned into a mosque some seven months before his visit at the end of May 1591, it was the case that S. Sophia had been converted many years previously ("fatta molti anni sono moschea").

b. According to $\mathrm{Ste} \mathrm{phan} \mathrm{Gerl} \mathrm{a} \mathrm{c} \mathrm{h,} \mathrm{Tagebuch,} \mathrm{Frankfurt,} \mathrm{1674,} \mathrm{as} \mathrm{quoted}$ by Theocharides in the article given above (p. 56), the Metropolitan of Thessaloniki reported to the Patriarch in 1576 that the Turks held three large churches and three smaller ones. Since the Rotunda was still in Christian use, the large churches should be: the Acheiropoietos (converted immediately after 1430); S. Demetrios (converted in Hegira $898=1491$ ); and S. Sophia.

c. B a b ing er, cited above, quotes the geographical writings of Mehmed ben Ömer ben Bayazid (1555 - 1600) as stating that the conversion of S. Sophia was ordered by the Grand Vizier of Sultan Suleiman I (1520 - 66), namely Ibrahim Pasha, who was strangled on 15 March 1536 . He is said in this source to have founded a minaret and a fountain in the garden at the same time.

These three pieces of evidence seem to point to the conversion of S. Sophia between 1520 and 1536. Kiel however criticises point (c) without taking into account points (a) and (b): on the grounds that Babinger incorrectly gives here the place of birth of the geographer as Thessaloniki (though in another work Babinger gave it correctly as Trebizond), Kiel goes on to suggest that he places too much trust in this authority. Kiel admits that the geographer for several years lived and worked in Thessaloniki, but says that his compendium Menazir ül Avalim, despite efforts to be accurate, is not without mistakes over the monuments of Thessaloniki e.g. about the exact nature of the enlargement of the Hamza Bey Mosque, and over the date of conversion of the Rotunda. I do not find Kiel's arguments decisive, and prefer to keep the period 152036 as the most likely on the present evidence. Kiel may have exaggerated Turkish ideological reasons for church conversion, which might as often have occurred as the Muslim population expanded and caused the need for more mosques. It follows from this dating of the conversion of S. Sophia that the nineteenth century references to the Rotunda as the Old Metropolis probably refer to its status in the sixteenth century and not in the Middle Byzantine period, as Theocharides supposed.

31. The o phanes, Chronographia, (ed. de Boor), $456-7$. 
musicians) into Thrace (going to Berroia, which was renamed Eirenopolis -now Stara Zagora- and to Philippopolis, to found Anchialos). The foundation of S. Sophia would fit well into this period of optimism and expansion immediately after $783^{32}$. Thessaloniki remained of course in an isolated and dangerous position and prudence may have led to as rapid as possible a building campaign for the church (using spolia as available). The non-figurative character of the mosaics may then have been planned and even executed before the Council of Nicaea in 787; alternatively the absence of figures reflects ecclesiastical caution. It is conceivable that the mosaic decoration was confined to the sanctuary at this period (a feature, it would seem, of some pre-iconoclastic churches), but the whole church might at this time have copied the decoration of the Great Ghurch at Constantinople and contained a cross at the apex of the dome.

It has been the aim of this paper to give reasons for dating the foundation and a first decoration of S. Sophia to the period immediately after the imperial campaign of $783^{33}$. This conclusion would be impossible to maintain if the interpretation of recent observations in the church by Theocharidou is correct ${ }^{34}$. Her publication of new technical is to be very much welcomed, but I must give reasons why her grounds for dating the superstructure of the church before Iconoclasm must be immediately discounted ${ }^{35}$.

Theocharidou believes it possible to date the cupola inscriptions in or before 690, and this year would therefore constitute a terminus ante quem for the construction of the church. What the inscriptions in their present state tell us is this:- that in November of the fourth indiction in the sixth millenium from the creation of the world in the time of archbishop Paul was done "this work" 36 . The information is given in two

32. There is evidence of building activity in Thrace and Asia Minor, and also the conscious proclamation of a Golden Age, cf. R. C o r m a c k, as cited in note 22 .

33. The precise form of the original church is not yet clear; $\mathrm{B} \mathrm{u} \mathrm{c} \mathrm{h} \mathrm{wald,} \mathrm{cited}$ in note 16 , criticises the earlier attempts.

34. Th e c h a ridou (1980), as cited in note 8 .

35. There is not space in the present paper to enter into a full discussion of the chronology of the cupola mosaics, but it should be emphasised that further investigation of the technical evidence of the garland is clesirable. The study of Theocharidou seems to establish firstly that the two inscription panels are relatively earlier than the Ascension; and secondly that there were originally two further inscriptions. Less conclusive is the evidence so far presented that the garland was set relatively earlier than the composition above. The evidence of the setting beds needs to be investigated all along the lower edge of the garland.

36. The order of the two inscriptions followed by Theocharidou seems to me pre- 
separate sections, neither of which have survived in a complete form. The panel on the north (left) side of the cupola is complete in its lettering except for the ending of the date: only a stigma is preserved, and so the precise year within 6000 is no longer given. The other panel on the south (right) side of the cupola is more fragmentary, and has lost the first and last three letters of each line. These areas of loss were at some time made good by the setting of the garland in the missing areas. It is not possible to say what was the original lateral framing or full dimensions of these truncated inscriptions ${ }^{37}$. Although Theocharidou is able to mark in her photographs the sutures between the inscriptions and the garland, the alterations made in the red glass framing above the north inscription and the state of the original red ceramic framing of the south inscription effectively conceal the original format of the panels. It is therefore unconvincing to argue, as Theocharidou does, that because the upper two lines of the north panel are complete on their right side, consequently the third line which now ends with the first letter of the millenium could not have extended for more than one further letter. Indeed in the area which she believes was available for the missing letter, there is scarcely space for the candidates she ultimately proposes (nu, pi, or sigma). It must be admitted that so far this criticism of her reconstructions of the original panels rests on the lack of evidence, and that her description of the north panel may seem attractive on esthetic grounds, for it would make the inscription symmetrical. The suggestion that the year involved was one that could be expressed in two numerals only must therefore be followed further.

Any discussion of this inscription must work from the premise that the mosaicist correctly harmonised the indiction with the year of creation, and that the year in question is one in which November falls in the fourth indiction. Theocharidou considers there to be only two occasions after 690 when the conjunction of a two numeral year 6000 with this in-

ferable to that of J. M. S p i e s e r, as cited in note 6, p. $260-261$ and plate 2 (the reverse order). Spieser summarises in his note the reasons given in my thesis for dating the inscription to November $885(=6394)$.

37. The south panel now measures 1.07 metres in width and was originally wider to contain four missing letters; the north panel now measures 1.08 metres and in the opinion of Theocharidou contained only one more letter. For reasons given below, I believe that there are two or more likely three letters missing, and that therefore the original panels were of roughly equal width. As for the nature of the lateral completion of the panels there are several possibilities to judge from the pre-iconoclastic mosaics of S. Demetrios (e. g. a tabula ansata form, space-filling birds etc. in the ground, or plain borders). 
diction occurs, namely $6500(=991)$ and $6800(=1291)$; these candidates she eliminates on the grounds that stylistically the Ascension mosaic cannot be as late as either of these two dates, but that it must postdate the inscriptions. She could have supported this conclusion by the evidence of palaeography, for the letter forms would seem to exclude a date later than the middle of the tenth century. Actually there is a much more conclusive reason for eliminating these two years: the November of 6500 as well as that of 6800 falls in the fifth indiction. No year of the Byzantine era of this kind could ever have its November in a fourth indiction, and it follows that if the inscription contained only two numerals, it could not be using the standard era. Theocharidou seems to have realised this, despite her miscalculation, for in turning to the pre-iconoclastic period she suddenly shifts into using the so-called Protobyzantine era, which differs from the standard era in its tabulation from the origin of the world ${ }^{38}$. At this point two difficulties must be mentioned which should have taken into account. The first is whether there is any justification for supposing that this system of dating was in use in epigraphy in Thessaloniki in the fifth, sixth, or seventh centuries. The second is whether the use of the era of creation could have been used in such an inscription before the late seventh century, since the earliest epigraphical examples are recorded only in 693 and 704 (in the graffiti of the Parthenon) ${ }^{39}$. One or other of these difficulties cast doubt on all the years envisaged by Theocharidou, viz. 6005, 6020, 6050, 6080, 6110, and 6200 (which she incorrectly transcribes as 495, 510, 540, 570, 600, and 690).

On the assumption that the cupola inscription refers to the Protobyzantine era, Theocharidou comes to the conclusion that it refers to one of the years 540, 570, or 690. Even if it had been possible to accept the steps leading this to this conclusion, all of which are doubtful, there is now found to be one inescapable flaw. The Protobyzantine system is

38. This term and the justification of its use is due to V. G r u m e 1, La Chronologie, Paris, 1958, esp. p. $73-94$. His interpretation is upheld by the recent analysis of the Chronicon Paschale: J. B e a u c a m p, R. B ond o ux, J. L e for t, M. Fr. R o u a n, I. S or li n, Le prologue de la chronique pascale, Travaux et Mémoires 7 (1979), 223 - 301.

39. Gf. I. Š e vč e n k o, An Inscription commemorating Sisinnios, "curator" of Tzurulon (A. D. 813), Byzantion 35 (1965), 564 - 74. For the Parthenon graffiti, see

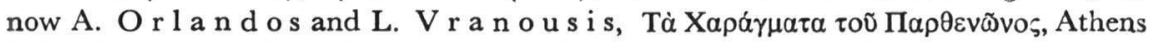
1973. G. F o s s, Three Apparent Early Examples of the Era of Creation, Zeitschrift für Papyrologie und Epigraphik 31 (1978), 241 - 146, reiterates the unlikelihood of documents with the use of the era of creation before the late seventh century. 
discussed at length by Grumel who shows that its crucial feature is that the year begins on $21 \mathrm{March}$; he is aware of the consequent problem in determining where the indiction fell, and gives the rules for discovering this ${ }^{40}$. If these rules are followed for the Protobyzantine years proposed by Theocharidou, it is discovered that in each case November of these years falls not in the fourth indiction but in the fifth (the correct equivalent is November 541,571, and 691). One can be quite categorical that any year where November falls in the fourth indiction cannot be expressed using only two greek numerals, whether the era is Byzantine or Protobyzantine. In other words, the cupola inscription must originally have contained three or four numerals, and the width of each panel was probably roughly equivalent ${ }^{41}$. The method followed by Theocharidou and the conclusion that the inscription must belong before Iconoclasm can be eliminated from further consideration. In the present state of research, it remains reasonable to propose the period 780 to 797 both for the foundation and the first sanctuary decoration of S. Sophia. The precise date of the cupola inscription remains an open question ${ }^{42}$.

40. V. Grume l, p. $202-203$.

41. Cf. note 37 above. If a three numeral date is to be canvassed, one candidate is the year 6304 (=November 795). The difficulty is in postulating an unknown archbishop Paul who would be responsible for completing the decoration of the church after the death of Theophilos; such a candidate is difficult to fit into the tight sequence in the period evidenced by P e ti t, Les Évêques de Thessalonique, Échos d'Orient 4 (1900 - 1), esp. 215 - 216.

42. If the inscription postdates 780 , as proposed in this paper, its evidence remains extremely enigmatic, for there exists well-documented information on the sequence of archbishops from this date onwards (contrary to the belief of certain art historians about the existence of an archbishop Paul in the eleventh century). The key publications of the list in cod. Vatican gr. 172, folios $177-81$, are: L. P e t i t, Le Synodicon de Thessalonique, Échos d'Orient 18 (1916-9), 236 - 254; V. L a u r e n t, La Liste épiscopale du Synodicon de Thessalonique, Échos d'Orient 32 (1933), 300 - 310; and J. Gouillard, Le Synodicon de l'Orthodoxie, édition et commentaire, Travaux et Mémoires 2 (1967), 1 - 316. To judge from other cities, such lists need to be use with care for they are not necessarily complete, with omissions from ignorance, carelessness, or deliberate falsification for reasons of theological odium. Usually, however, such list are in correct chronological sequence (cf. R. J. H. J en kins and C. M a n g o, A Synodicon of Antioch and Lacedaemonia, DOP 15 (1961), 225 - 242, and V. L a u r e n t, La liste épiscopale de la Métropole de Lacédémone, REB 19 (1961), 206 - 226). In the case of Thessaloniki, there may be a dislocation of Plotinos in the ninth century sequence, which adds to the difficulties of unravelling the dates in this period, see P. K a r l i n - H a y t e r, La date de Plotin, archevêque de Thessalonique, Byzantion 32 (1962), $129-131$. The normal interpretation of the list must be that between 770 


\section{THE ENTHRONED VIRGIN AND CHILD}

The second phase of mosaic decoration in the apse when the central cross was replaced by a figurative composition can only be dated by art historical considerations. The lack of any objective factors has led predictably to the usual discrepancy of solutions offered, which range from the eighth to the twelfth centuries ${ }^{43}$. In only one aspect is there any

and 1440 there were only two archbishops named Paul, and both held office in the ninth century; one is independently dated in the $880 \mathrm{~s}$ and his term of office could have included November of the fourth indiction of the year 885 (6394). This date would of course be very satisfactory as the date for the style of the Ascension mosaic, which could in any case hardly be later than the middle of the tenth century at the outside. But it now appears from the observations of Theocharidou that this date belongs to an earlier period in the history of the cupola than the Ascension. One possibility that might be considered is that $\mathrm{S}$. Sophia suffered serious damage at the time of the Saracen raid in 904 and the Ascension is a repair of this period (Arethas went to Hellas in late 905 - early 906 to reconsecrate churches, cf. J. H e r r i n, Aspects of the Process of Hellenization in the Early Middle Ages, Annual of the British School at Athens 68 (1973), $113-26)$. This possibility can only be seriously considered if the evidence of Cameniates is discounted and it is supposed that damage in the city was more extensive than usually believed $\mathrm{cf}$. A. P. $\mathrm{K} \mathrm{a} \mathrm{z} \mathrm{h} \mathrm{d} \mathrm{a} \mathrm{n,} \mathrm{Some} \mathrm{questions} \mathrm{addressed} \mathrm{to} \mathrm{the}$ scholars who believe in the authenticity of Kaminiates' Capture of Thessalonica, BZ 71 (1978), $301-314$.

43. Pelekanides (1973) dated the Virgin to two operations, one of the late eighth century, and the other to the second half of the twelfth century. Galavaris likewise, cited in note 4 , attributes the Virgin to two phases, apparently dating the first to the ninth century, and the second to the eleventh. Other opinions, of which a sampling is given here, had assumed the composition to be of one period. Kalligas, cited in note 5 , dated it after 843 .

A. G r a b a r, L'Iconoclasme byzantin, Paris 1957, p. 195, dated the Virgin to the same period as the cupola, the end of the ninth century. He considered the proposition that the mosaic contained as earlier version of the child, and rejected it; he did believe that the child had undergone some restoration.

V.N. L a z a r e v dated it to the ninth century, Painting of the eleventh and twelfth centuries in Macedonia, (in Russian), Actes du XIIe Congrès international d'études byzantines I, Belgrade, 1963, p. $105-134$. An eleventh century date was proposed by K. P a p a d o p o u l o s, Die Wandmalereien des XI. Jahrhunderts in der Kirche חava-

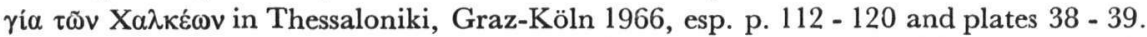

A date in the twelfth century was proposed by A. F r o low, La Mosaique murale byzantine, Byzantinoslavica 12 (1951), 180 - 209, and by P. J. N o r d h a g e n, The Mosaics of John VII (705 - 7 A. D.), Acta ad Archaeologiam et artium historiam pertinentia 2 (1965), 121 - 166, esp. 163, note 6. More specifically, V. J. D j u rić, La Peinture murale byzantine, XIIe et XIIIe siècles, Actes du XVe Gongrès International d'études byzantines, I, Athens, 1979, $159-252$, dates it to the first half of the twelfth century (unlike Pelekanides who opted for the second half of the century). 
unanimity, and this is in the characterization of the execution of the present Virgin and child as one of the least successful of Byzantine mosaics, a work of mediocre quality. If true, this lack of finesse will need some discussion.

In the years before the severe fire of 1890 , when S. Sophia was in use as a mosque, visitors reported the apse composition as obscured by placards and overpaint; Duchesne and Bayet record that what could be seen of the Virgin seemed very damaged ${ }^{44}$. By 1907, the mosaic had suffered further deterioration as a result of the fire, neglect, and the penetration of rain through the roof. Le Tourneau described the Virgin as heavy in appearance, poor in execution, and unpleasant in colour ${ }^{45}$. $\mathrm{He}$ observed the mosaic from close-to, and notes her garment with its complicated folds; he describes her flesh parts as highly modelled with highlights in white, colours in yellow and rose, and shadows in grey-green. Her features, he writes, are outlined in dark colours. The robe was richly coloured, with many scattered single tesserae of different hues (white, blue, green, red, etc.). The garment of the child was gold. Areas of loss in 1907 are visible on his photograph (Pl. 19a): a small round patch immediately above her halo, patches on the three parts of the maphorion where segmenta would once have been, and a patch in the garment over the right knee.

In the restoration of 1907, the roof was overhauled, the surface of the mosaic cleaned, and the areas of loss filled in with plaster (to be seen in Pl. 22). The next work in the apse was done in the 1941 restoration. Comparison of the earlier records with recent photographs shows that this work was not limited to the replacement of sections of the gold ground which were described above, but included the insertion of new tesserae into the areas of loss within the figure (Pls. 20 and 21).

It was from the scaffolding of 1941 that Xyngopoulos made his observation that has subsequently featured in discussion of the apse mosaics, and which has led me to choose this subject for this volume ${ }^{46}$. According

44. As cited in note 8: the garments of the Virgin were then described as 'bleu grisâtre'.

45. As cited in note 5 .

46. The observation of Xyngopoulos is reported by Kalligas and Galavaris, cited in note 4. Only Grabar seems to have regarded it critically. Galavaris in his discussion of iconography is incorrect to describe this throne with one cushion only, and this mistake invalidates some of his generalisations about the 'thokos' before the fourteenth century. His dating of the apse of S. Sophia at Constantinople through comparisons with seals is not acceptable. 
to Xyngopoulos, the mosaic has in it "traces of the foot of another child which must have existed before it was replaced by the present child. The traces of that foot indicated that the previous child was in a reclining position". This observation is crucial to the analysis of the apse mosaic made by Galavaris and Pelekanides, who both believe that a change of iconographic type occurred in the period ${ }^{47}$. After further observation from a scaffolding in 1961, Pelekanides wrote two papers on the subject and in these he interpreted the colour change visible at a level above the Virgin's right hand and running horizontally (see Pls. 20 and 21) as a suture; the lower part of the mosaic would then date from an earlier period than the upper part ${ }^{48}$.

In order to assess the theory of Pelekanides, it is necessary to look closely at the figurative composition fitted into the pre-existing mosaics. The secondary work consists of the fill of the top of the vertical arm of the original cross, and of a composition of an enthroned Virgin and Child. The Virgin sits on a backless throne on which are,placed two cushions (red in front, blue-green behind), which in turn are covered by a piece of decorated material. The Child is in a sitting position, but appears as if suspended against the Virgin's breast, for her left hand rests on the shoulder but her right, with a handkerchief, is held below the Child's feet and seems more to be supporting a cushionlike bunch of material over her abdomen.

It is true that some features of this composition might seem to point to two phases of execution: the line running horizontally across the sleeve of the Virgin's right arm just above the cuff is to be seen in recent photographs (where a lighter area above changes into a darker area below). Pelekanides might have added to this observation the odd way that the Child seems to levitate without support from the Virgin's right hand, and that various anomalies of colour and drapery emerge when an attempt is to describe the Virgin's garments. Despite these infelicities, however, the notion of two separate phases of work is difficult to maintain if the following points are all taken into account:

1) there is no clear line of suture across the composition;

2) some modelling lines of tesserae seem to run consistently through the area of colour change in the sleeve;

47. Pelekanides (1973) characterized this as a change from a "Hodigitria' to a 'Platytera'.

48. It is difficult to judge from the two studies of Pelekanides exactly how sharp a break he understood. 
3) a 'levitating' Child is not unparalleled (for example in the apse of the Koimesis Church at Nicaea);

4) the Virgin does wear a recognisable stola and maphorion. Irrational changes of colour within garments occurs in other works (for example, in the enthroned Virgin in the Egbert Psalter in the Museo Archeologico Nazionale at Cividale);

5) if the two phases require a separation in date of the two hands of the Virgin, this is stylistically unconvincing.

Two final points need particular emphasis as they can only finally be resolved with investigation from a scaffolding. The first is the claim by Xyngopoulos that there were traces of the feet of an earlier Child than the one now represented. No photographs or observation in the church seem to confirm his identification. I believe that this observation should be discounted as a basis for argument. The second point requires study of records and photographs made before 1941 (Pls. 19a-b, 22). In these, the proposed line of suture on the sleeve is not visible. It could be that before 1941 the accumulation of dirt concealed the surface here, but it seems more likely that the cleaning undertaken at that time revealed artificial discoloration, due, for example, to seepage of rainwater or to some chemical condition or to some other damage. Discoloration in turquoise was one kind of deterioration noticed in the apse of S. Sophia at Constantinople ${ }^{49}$.

The notion of two phases within the figure of the Virgin and Child can therefore be rejected on several grounds, but it is necessary to take a more positive approach and to ask whether the composition can be seen as the product of one operation and what can be learnt about the mosaicist. The first question to ask is whether the stylistic treatment is consistent throughout. Several similarities of treatment are easily recognised in the Virgin and in the Child: the flesh of both is modelled in the same way, and the garments modelled by thin rows of tesserae (dark on the Virgin's garment, and red on the Child's gold garment); the base of the abdomen is portrayed in both through wedge - shaped hatching; in both the upper garment is characteristically bunched up beside the hip on the right side. In addition to such consistencies of style, the homogeneity of the composition can be supported on technical grounds, for one method of working is to be observed throughout this

49. C. Mango and E. J. W. Hawkins, The Apse Mosaics of St Sophia at Istanbul, DOP 19 (1965), $115-151$. 
phase $^{50}$. This is the deliberate admixture of silver tesserae into areas of gold. The occurrences of this technique can be listed:

1) in the fill of the vertical arm of the cross, and so distinguishing this area from the original gold ground;

2) a few silver tesserae occur in the four rows of gold trim of the halo of the Virgin on the right sides. The silver cubes are in the two interior rows;

3) a few silver tesserae occur in the Child's garment over his left shoulder between the fingers of the Virgin's left hand;

4) one silver tessera in the gold band on the Virgin's right shoulder;

3) there is a scattering of silver tesserae across the gold upper surface of the footstool.

This technique, whether used to brighten a surface subject to changing light conditions or for some other reason, distinguishes the Virgin and Child composition from other mosaics in the church, and adds support to the opinion that this phase is homogeneous ${ }^{51}$. If the work was the responsibility of one mosaicist, what is the explanation for the awkward design and for the infelicities of drapery?

It was never easy to design a composition within the deeply curving apse semidome ${ }^{52}$. On this occasion the designer had to operate with economy within a space cut from the pre-existing ground. It must have been harder to draw a seated rather than a standing figure: even in the apse at Constantinople this difficulty was felt, and the Virgin's right knee is too small compared with her left. Critics of the Thessaloniki figure complain of squatness and heaviness, with the head too large for the body. There is some truth in these adverse judgements, although some photographs tend to exaggerate such trends, and the mosaicist seems to have experienced difficulty in carrying out his commission.

50. These observation are made from floor level only and need confirmation.

51. The admixture of silver and gold tesserae has been recorded in Constantinople over a limited time only: in S. Eirene, in the apse, and in S. Sophia, in the apse, north Tympanum, Alexander panel, narthex lunette, and south-west vestibule lunette. But I have also observed the technique in eleventh and early twelfth century mosaics in Kiev (to be attributed to artists from Constantinople): e. g. in the apse of S. Sophia, and in the panel of S. Demetrios from the Church of S. Michael (now in the Tretiakov Gallery, Moscow).

52. It was equally a matter of some expertise to design a cross in an apse to be seen correctly from the floor of a church, cf. Un d e r w o od, cited in note. 21. Grabar thinks this Virgin was a total failure. 
The mosaicist who designed the Virgin and Child composition in the apse of S. Sophia at Constantinople had the problem of an exceptional high and difficult vault, but at least he was able to work on a surface stripped of pre-existing mosaics. It has been demonstrated that he made his design from a platform more or less level with the windows of the apse semidome, and that the proportions of the figures are seen correctly by an observer in this position ${ }^{53}$. Consideration of photographs of the apse at Thessaloniki help to understand the process of its design. In a photograph from the scaffolding at cornice level (Pl. 19a), the seat and footstool appear horizontal, and the posts of the throne vertical, but the halo on the contrary is distorted. From the floor (Pl. 22), photographs can be taken looking sharply upwards where the halo is correctly circular whereas the footstool sags in the middle and the posts come apart at the base.

An explanation can be proposed for this incongruity of design. Did the mosaicist operate not from a single viewing point but from two separate points? This explanation does not imply two periods of work, but suggests that the work was done in two stages, presumably the upper part of the composition first. If this was the case, then one would expect the artist after working on a higher platform, to lower this to complete the second stage of the design. This procedure might have resulted in a junction between the two levels, which would be a possible explanation also for the horizontal 'suture'. ${ }^{54}$

It has been argued in this paper that the apse mosaics of S. Sophia belong to two separate phases, and that the first can be dated by the objective evidence of the monograms. It is not likely that second figurative phase was a replacement for the cross soon after the Council of 787 and which has survived the second period of Iconoclasm ${ }^{55}$, and neither is there good reason to suppose that the cross was replaced immediately after the triumph of Orthodoxy in 843 (the precise date for the restoration at Nicaea is not known, there was a delay until 867 before the

53. Discussion by Mango and Hawkins, cited in note 49 .

54. Such a pontate might also be the explanation of the horizontal line across the legs of the apostles in the Church of S. Michael at Kiev, see V. N. L a z a r e v, Old Russian Murals and Mosaics, London, 1966, plates 52-53. However these mosaics were the victims of the attempt to sweep away Old Kiev in the 1930s and the line may have occurred in restoration after its removal to its present location in the gallery of S. Sophia at Kiev.

55. Pelekanides (1973) thought the first version of the enthroned Virgin belonged to the period after the Council of Nicaea and before 797 . 
apse mosaic of S. Sophia at Constantinople was restored, and the apse cross in S. Eirene was never replaced with a figure). One might have expected the post-iconoclastic redecoration of the cathedral of Thessaloniki to have been inaugurated with a new apse scheme, but neither the 'logic' of the present programme (the incarnation in the apse and the Ascension in the cupola) nor a stylistic comparison of the apse with the cupola give any good grounds for attributing the apse to the ninth centu$\mathrm{ry}^{56}$. Stylistic comparisons with later monuments are more convincing.

A major difficulty in dating the Virgin is that so many of stylistic elements (shapes of the lips and such like) belong to a standard repertory of forms, particularly in provincial wallpaintings. Indeed the streaky modelling of the flesh is reminiscent of brushwork, and this is just one more indication that the artist or artists involved may only rarely have worked in the medium of mosaic. To me, the closest parallel for the style of the face of the Virgin is to be found in wallpaintings; these are to be found no further distant than in the narthex of S. Sophia itself. In the face of S. Theodora of Thessaloniki all the features of the treatment of the Virgin in the apse are to be found (such as the highlights along the nose, and the shape of the shadows below the eyes, lips, and chin $)^{57}$. The date of the narthex paintings of S. Sophia has been generally accepted as eleventh century, and probably in the second quarter of the century. The point of reference for the dating is the high quality painting of the church of the Panagia Chalkeon of 1028, and the artist employed here exhibits all the characteristics of one trained in the current trends of Constantinople and may have been the man responsible for introducing these into Macedonia ${ }^{58}$. Both the apse mosaics and the narthex

56. A. G r a b a r, L'Iconoclasme byzantin, Paris, 1957, esp. p. 195 and 256 makes a case for a ninth century date on grounds of style and programme.

57. The basic publication of the wallpaintings is $\mathrm{Pelekanides}$ (1955); for Theodora, see plate 83, fig. 1. The eleventh century date is accepted by D. Mou ri k i, The Portraits of Theodore Studites in Byzantine Art, JÖB 20 (1971), 249 - 280, who attributes the figure to be identified as Theodore (not Eleutherios, as by Pelekanides) to approximately the same date as the mosaics of Nea Moni on Chios. The date in the second quarter of the eleventh century is also accepted by B. L. V o c ot o poulos, The Concealed Course Technique; further examples and a few remarks, JÖB 28 (1979), $247-260$. He is prepared to connect the programme of wallpainting with a Middle Byzantine remodelling of the church in the masonry of which he observed the recessed brick technique.

58. The use of the recessed brick technique here (easily visible since the earthquake and recorded by V o c o t o p o u los, op. cit.) is one argument for a Constantinopolitan mason, while the origin of the artist in the capital is supported by the compari- 
paintings of S. Sophia can also be closely compared with the wallpaintings in the church of S. Sophia at Ohrid which belong to the rebuilding datable to $1037-1056^{59}$. Further comparisons can be made between the drapery of the apse Virgin at Thessaloniki and the Annunciation Virgin at S. Sophia at Kiev and in the naos of the catholicon of Vatopedi.

Stylistic considerations have led to a dating of the second phase of the apse and also of the narthex paintings of S. Sophia to the second quarter of the eleventh century. Presumably both areas were redecorated as part of a major restoration of the cathedral (another question is whether work was also done in the cupola on this occasion). I would like to suggest that the same artist was responsible for both areas, and that his experience lay in painting; but he had no choice in the apse except to replace mosaic with mosaic. His commission included the portrayal of a cycle of monastic saints in the narthex, a particular ecclesiastical interest in this period, and the long-delayed removal of the cross from the apse. It is possible that this programme of work was forced on the archbishop from some recent damage to the church - the severe earthquake of November to January $1037 / 8$ might fit the chronology ${ }^{60}$ - but there is a good historical context for the overhaul of the cathedral in this period. With the ending of the Bulgarian threat to this region after the triumph of Basil II, Thessaloniki entered a period of prosperity and this was marked by an expansion of church building in the city and surrounding region ${ }^{61}$. The dating of both phases of the apse mosaics proposed in this paper suggests that in each case art is a visual document of the economic and spiritual revival of the city, stimulated by imperial conquests in Macedonia.

son with the Laura Skeuophylakion Lectionary made by $\mathrm{P}$ a p a d o p o u l o s (following the dating of this manuscript to the reign of Basil II, as argued by $\mathrm{K}$. Weitzmann).

59. Cf. A. W. E p s t e i n, The Political Content of the Paintings of Saint Sophia at Ohrid, JÖB 29 (1980), 315 - 325. An association between the apse mosaic at Thessaloniki and the sanctuary paintings at Ohrid was also suggested by Papadopoulos.

60. For a list of earthquakes see V. Gru me l, La Chronologie, Paris, 1958, p. $476 \mathrm{ff}$.

61. One documented personality in this period of expansion is S. Photios of Thessaly who is said to have founded several monasteries, and to have encouraged the citizens with prayers at the time of the Bulgarian threat; see V. G r u m e l, Le fondateur et la date de fondation du monastère thessalonicien d'Acapniou, Échos d'Orient 30 (1931), 91 - 95. For a dating of $\mathrm{H}$. Anargyroi at Kastoria to the first third of the eleventh century, and probably soon after the Chalkeon church, see A. W. E p s te in, Middle Byzantine Churches of Kastoria: Dates and Implications, Art Bulletin 62 (1980), 190 - 207. 
There is one further conclusion to be considered. Xyngopoulos has been much criticised for exaggerating the importance of Thessaloniki as a creative provincial centre ${ }^{62}$. Rightly so. Yet a modified theory of local patronage and local availability of artists seems to me unavoidable. Even in the case of S. Sophia which we have been considering and where the contacts of its clergy with Constantinople ought to have been very close, the indication of the quality of its decoration, if this factor can be taken seriously, is that the artist of the cupola Ascension was brought from the capital, but that the Virgin in the apse is one of the very few post-iconoclastic mosaics which could be attributed to an artist based in a provincial city.

R. CORMACK

62. His classic statement was: A. Xy n g p o u los, Thessalonique et la peinture macédonienne, Athens, 1955. 

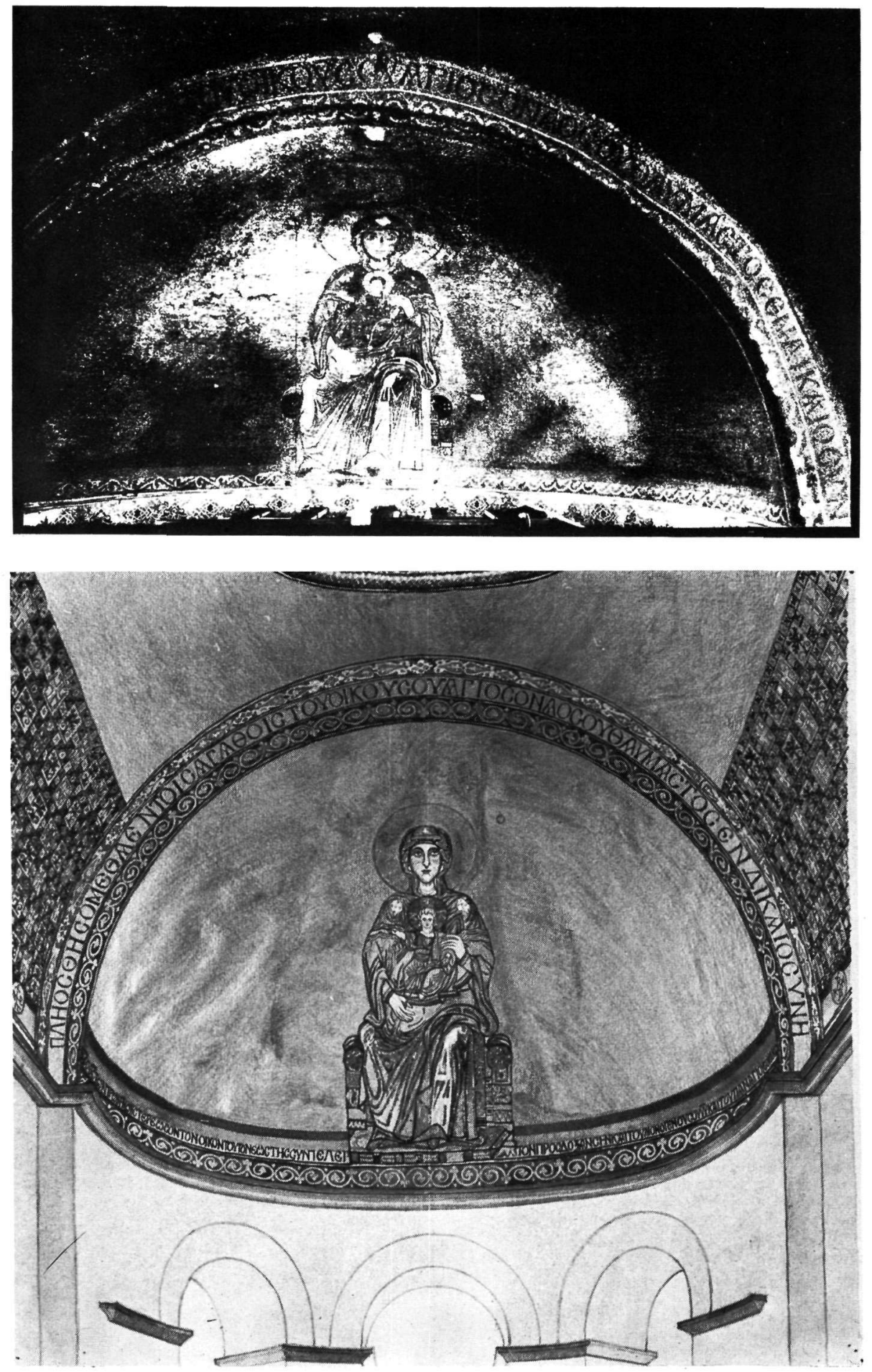

a. Apse of S. Sophia, Thessaloniki. a. Photographed in 1907 (photo. M. le Tourneau). b. Watercolour by William Harvey in 1908 (British School of Archaeology at Athens). 


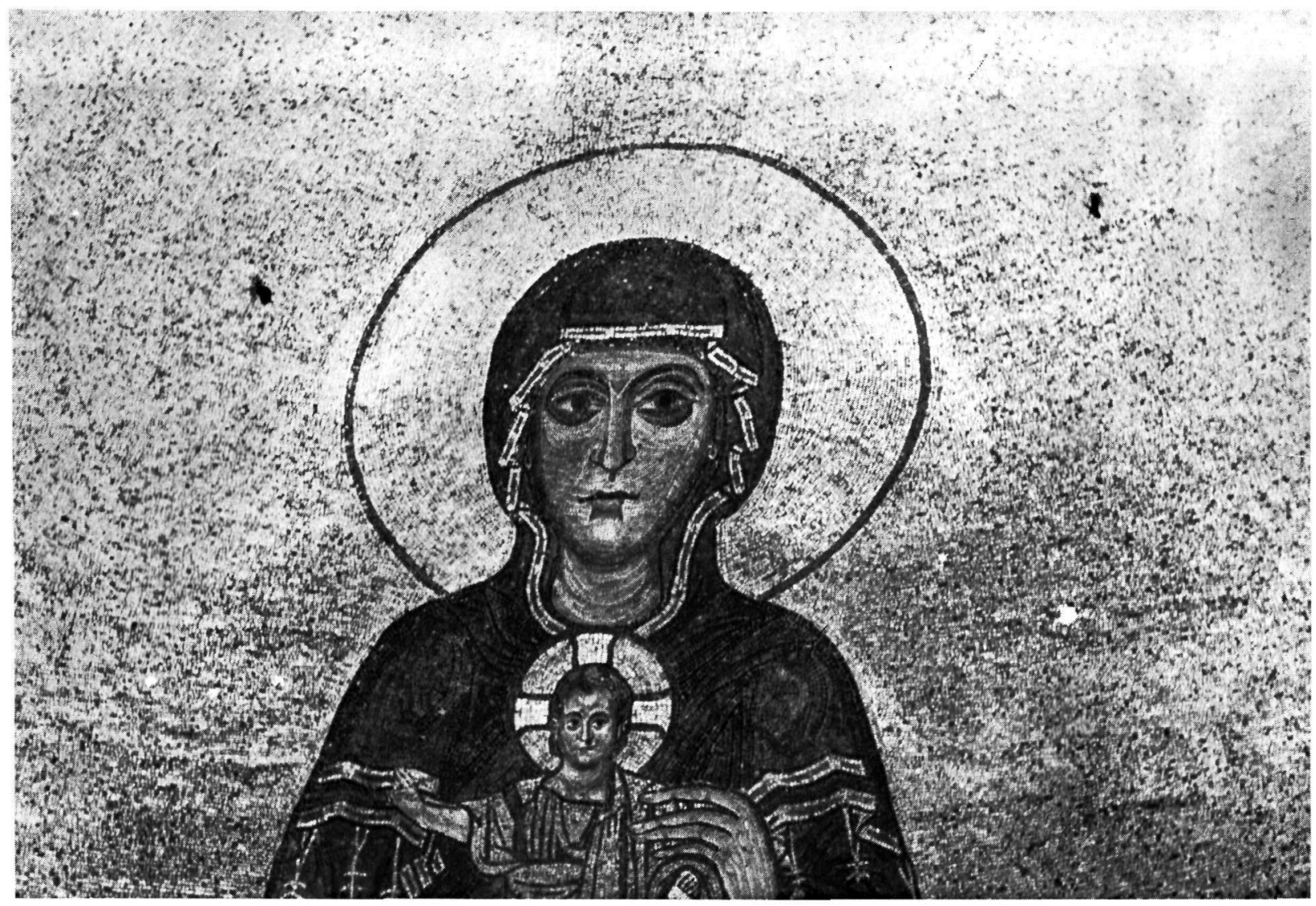

Virgin and Child, apse of S. Sophia, Thessaloniki; as in 1965 (photo. R. Cormack). 


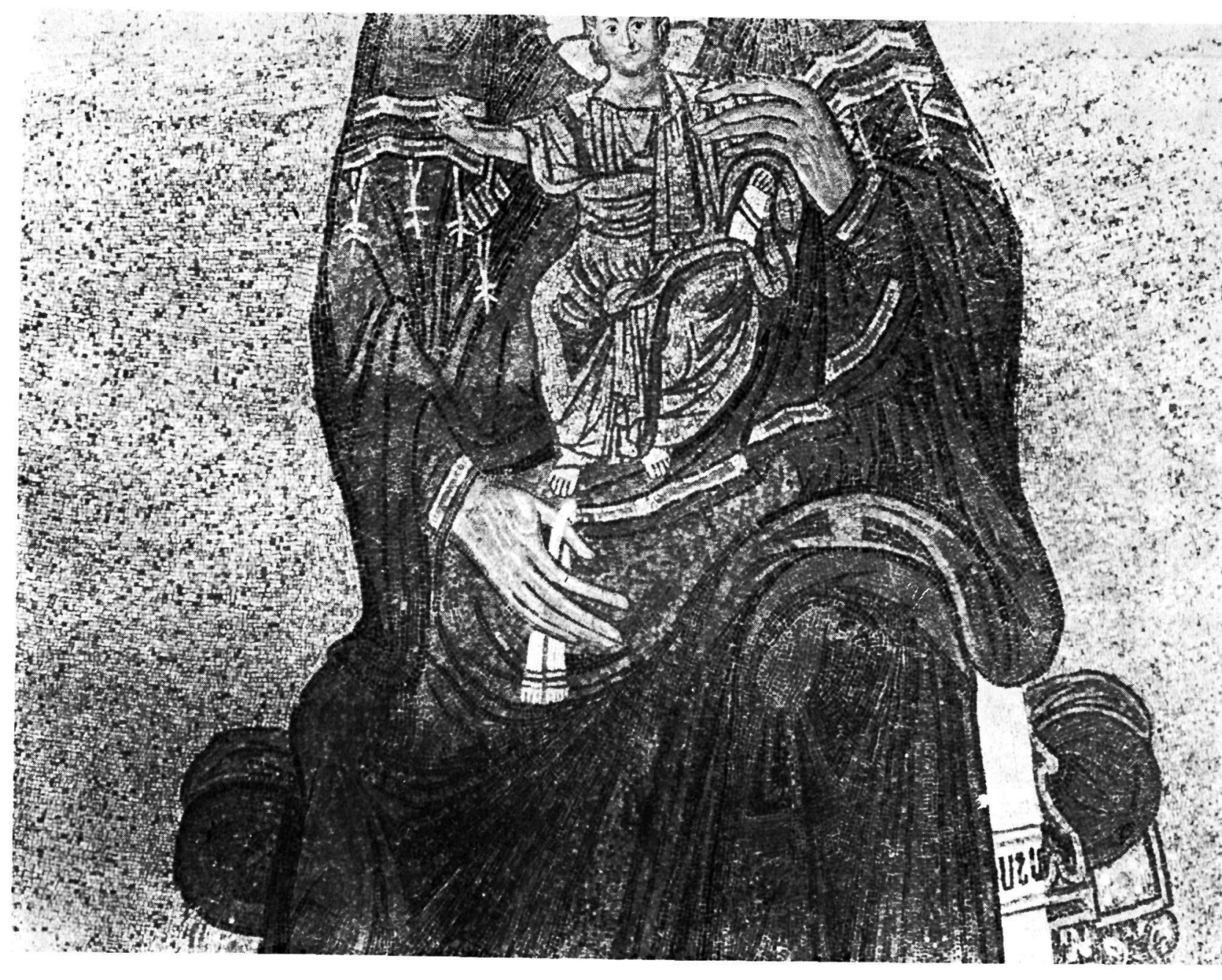

0
0
0
3
2
2
2

Virgin and Child, apse of S. Sophia, Thessaloniki; as in 1965 (photo. R. Cormack). 


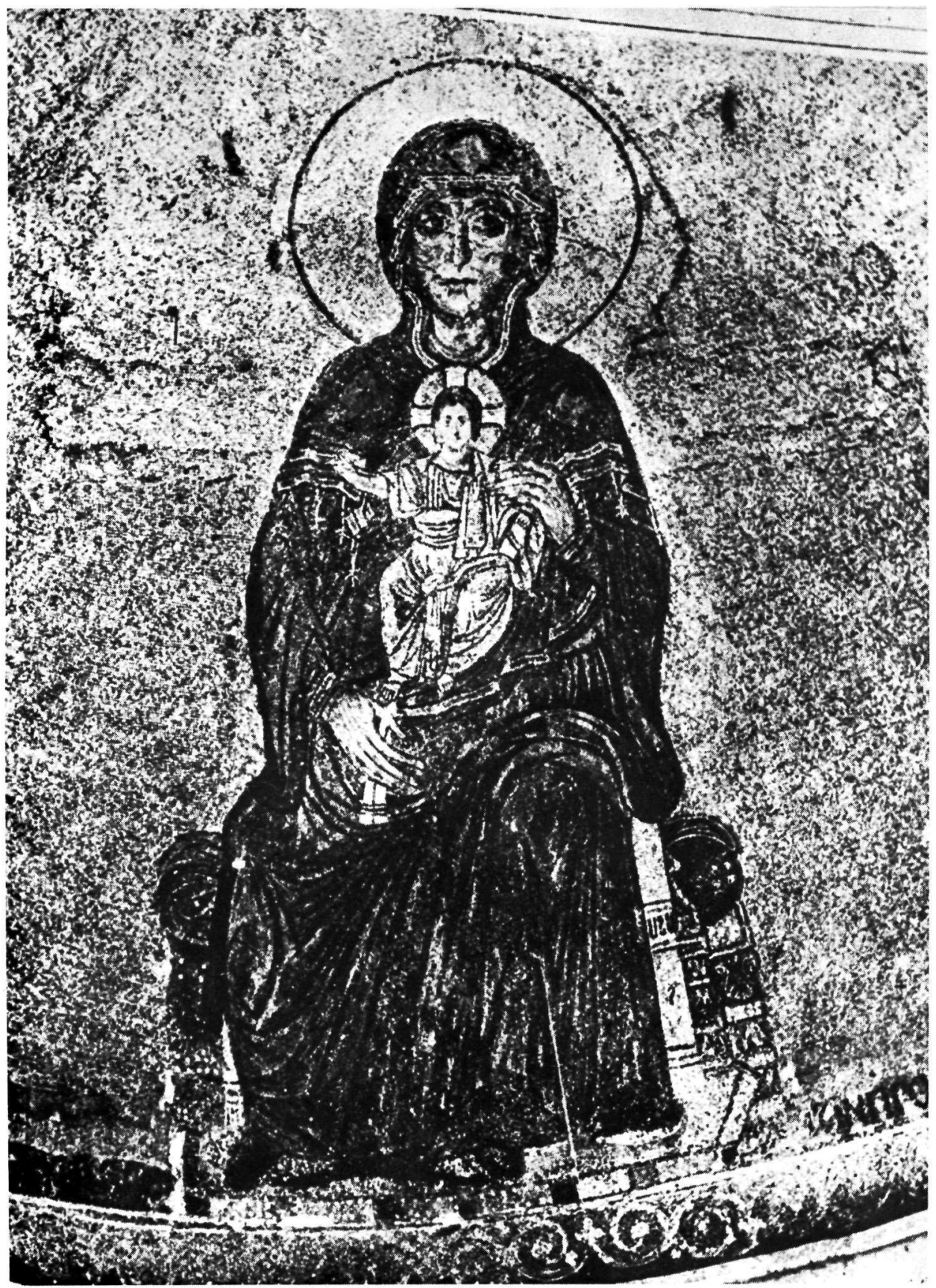

Apse of S. Sophia, Thessaloniki: photographed soon after 1912 (photo. F. Boissonnas). 